\title{
Pengaruh perbedaan waktu inseminasi buatan terhadap keberhasilan kebuntingan Sapi Brahman Cross
}

\section{The effect of differences time in artificial insemination toward succesful Brahman Cross pregnancy}

\author{
Fakhri Alfi Annashru*, M. Nur Ihsan, Aulia Puspita Anugrah Yekti dan Trinil Susilawati \\ Fakultas Peternakan Universitas Brawijaya Malang
}

Submitted : 04 August 2017, Accepted : 05 September 2017

\begin{abstract}
ABSTRAK : Tujuan penelitian ini adalah mengetahui pengaruh perbedaan waktu IB terhadap keberhasilan kebuntingan sapi Brahman Cross ditinjau dari waktu dan Non Return Rate (NRR) . Materi dalam penelitian ini adalah sapi betina Brahman Cross berjumlah 75 ekor, 35 ekor di IB dengan interval 8-12 jam dan 40 ekor di IB dengan interval 0-4 jam. Metode yang digunakan dalam penelitian adalah percobaan lapang. Pemilihan sampel ternak menggunakan Purpose Sampling dengan kriteria sapi betina dewasa bobot badan $>$ 250, umur 1,5 - 2 tahun, sehat, dan bebas dari gangguan penyakit dan minimal memiliki kondisi berahi. Bahan dalam penelitian ini adalah semen beku sapi Brahman yang diperoleh dari Balai Inseminasi Buatan (BIB) Lembang, Bandung Jawa Barat dengan motilitas 35-40\%. Variabel dalam penelitian ini adalah kebuntingan sapi dan munculnya tanda-tanda berahi. Data yang diperoleh dianalisis secara deskriptif analitik dan uji chi-square. Data pendukung berupa pakan dan nilai dari heat detector (HD). Hasil penelitian menunjukkan bahwa sapi Brahman Cross yang di IB pada interval 0-4 jam memiliki CR berdasarkan NRR ${ }_{1}$ lebih tinggi, yakni 70\% dibandingkan dengan yang di IB pada interval 8-12 jam memiliki nilai CR 37,14\%. Berdasarkan uji chi-square dinyatakan bahwa perbedaan waktu IB pada sapi Brahman Cross adalah $\mathrm{p}<0,05$ yang artinya perbedaan waktu IB pada sapi Brahman Cross berpengaruh terhadap keberhasilan kebuntingan. Disarankan IB pada 0-4 jam setelah terdapat tanda-tanda berahi dan dilakukannya pengamatan $\mathrm{NRR}_{2}$ hingga $\mathrm{NRR}_{3}$ dan Pemeriksaan kebuntingan (PKB) untuk mengetahui keberhasilan kebuntingan pada sapi Brahman Cross secara sempurna.
\end{abstract}

Kata kunci : Inseminasi buatan, sapi brahman cross, siklus estrus, kebuntingan

\begin{abstract}
The purpose of this research was to evaluated the difference of AI time towards Brahman Cross pregnancy rate determined by time and Non-Return Rate (NRR). The subjects in this research are 75 female Brahman Cross. Methods that were used during this research were field testing. Selection method of the sample livestock used is Purpose Sampling with criteria: Heifer with weight $>250 \mathrm{~kg}$, aged 1,5 -2 years, healthy, and free from any disease, and at least have mating urge. Materials used during this research were frozen cow semen that acquired from Balai Inseminasi Buatan (BIB) Lembang, Bandung, West Java with $35-40 \%$ motility. The variables were Cow's pregnancy and mating urge's symptoms. Data acquired during this research were analyzed descriptively and chi-square tested. Supportive data were food and value from heat detector (HD). Research result shows that Brahman Cross species which AI within 0-4 hours interval have higher CR according to NRR1, which is $70 \%$. Compared with the other breed that AI within 8-12 hour interval, which had 37,14\% CR value.According to chi-square test concluded that difference of AI time off is affecting the pregnancy rate. It is advised that AI is executed during 0-4 hour interval after showing mating symptoms and further review about the difference between AI execution time of Brahman Cross and further observation of NRR2 until NRR3 and also Pregnancy Test to know the pregnancy success rate of Brahman Cross.
\end{abstract}

Keywords : Artificial insemination time, brahman cross, estrous cycle, pregnancy

\footnotetext{
*Corresponding author: Fahrialfiannashru@gmail.com
} 


\section{PENDAHULUAN}

Impor sapi bakalan sering dilakukan untuk memenuhi kebutuhan pasokan daging konsumsi. Mayoritas jenis sapi yang di impor di Indonesia adalah sapi Brahman Cross (BX). Sapi potong yang dijadikan bakalan pada industri penggemukan di Indonesia berasal dari Australia dan berasal dari jenis bangsa sapi Brahman Cross (BX) (Zajulie dkk., (2015). Sapi Brahman Cross banyak diminati oleh feedloter dikarenakan pertambahan bobot harian (Avarage Daily Gain = ADG) dan persentase karkas lebih tinggi dengan komponen tulang lebih rendah dibandingkan dengan sapi lokal (Firdausi dkk., 2012). Namun sapi Brahman Cross memiliki karakteristik reproduksi jelek dengan nilai S/C 2,27. Selain impor bakalan unggul, faktor lain yang menyebabkan terjadinya kegagalan peternakan sapi potong adalah kurangnya pengetahuan mengenai perkawinan, baik secara alami atau kawin suntik (Inseminasi Buatan).

Inseminasi buatan (IB) merupakan sebuah teknologi reproduksi bertujuan untuk meningkatkan efisiensi reproduksi dan penyebaran bibit unggul secara merata serta dapat mencegah penyebaran penyakit akibat dari penularan kelamin (Susilawati, 2011). IB merupakan program yang telah dikenal oleh peternak sebagai teknologi reproduksi ternak yang efektif. Keberhasilan program IB dipengaruhi oleh beberapa hal antara lain, ternak betina itu sendiri keterampilan inseminator, ketepatan waktu IB, deteksi berahi, handling semen dan kualitas semen (Susilawati, 2011). Pamayun dkk. (2014) menyatakan bahwa keberhasilan IB sangat tergantung pada waktu inseminasi. (Ramli dkk., 2016) menambahkan penentuan waktu berahi sapi betina perlu di tangani dengan tepat.

Waktu IB sangat berpengaruh terhadap kebuntingan sapi, namun waktu berahi tidak dapat ditentukan dengan pasti sehingga ditentukan waktu patokan IB sebagai berikut : apabila sapi betina yang akan dikawinkan terlihat gejala berahi pada pagi hari maka pada pagi berikutnya dikawinkan. Sebaliknya bila terjadi berahi pada sore hari, maka pagi berikutnya dikawinkan (Ihsan, 2010). Ketetapan waktu bertujuan agar spermatozoa dapat bertemu dengan sel telur untuk terjadi pembuahan dengan sempurna sehingga terjadi kebuntingan.

Lama berahi 18-19 jam dengan waktu ovulasi terjadi 10-11 jam setelah estrus berakhir. Namun menentukan lamanya berahi dan waktu ovulasi dilapangan sangatlah sulit, sehingga perlu dicari solusi untuk menentukan waktu IB yang tepat.Waktu terbaik untuk melakukan inseminasi buatan (IB) adalah 9-24 jam setelah tanda-tanda berahi pertama muncul (Sugiarti dan Siregar, 1999). Penelitian ini bertujuan untuk mengetahui pengaruh perbedaan waktu inseminasi buatan terhadap keberhasilan kebuntingan sapi Brahman Cross

\section{MATERI DAN METODE}

Penelitian ini dilakukan di breeding PT. Pasir Tengah Desa Citampele, Mentengsari, Cikalongkulon, Kabupaten Cianjur, Jawa Barat. Penelitian dilakukan selama 39 hari. Pada tanggal 17 Januari 25 Februari 2017.Materi yang digunakan adalah sapi betina Brahman Cross berjumlah 75 ekor, 35 ekor di IB dengan interval 8-12 jam dan 40 ekor di IB dengan interval 0-4 jam. Sampel yang dipilih secara purpose sampling dengan kriteria sapi betina dewasa bobot badan $>250 \mathrm{~kg}$, umur 1,5 - 2 tahun, sehat, dan bebas dari gangguan penyakit yang sedang dalam kondisi berahi yaitu antara lain : vulva merah, vulva membengkak, vulva hangat, vulva berlendir, dan ternak mau dinaiki dan menaiki. Bahan dalam penelitian ini adalah semen beku sapi Brahman yang diperoleh dari Balai Inseminasi Buatan (BIB) Lembang dengan motilitas 35$40 \%$.

Metode yang digunakan dalam penelitian adalah metode percobaan lapang dengan sampel sebanyak 75 ekor 
sapi BX yang di IB dengan P1= Interval waktu 0-4 jam dan $\mathrm{P} 2=$ interval waktu 812 jam. Variabel yang diteliti adalah waktu berahi dan kebuntingan yang menggunakan metode NRR, yang mana dalam penelitian ini menggunakan $\mathrm{NRR}_{1}$ berpedoman pada Fernanda dkk. (2014) bahwa jika sapi yang di IB dan tidak berahi lagi selama 21 hari setelah IB maka dianggap bunting. Perhitungan $\mathrm{NRR}_{1}$ dirumuskan dengan

$$
\text { NRR1 }=\frac{\begin{array}{c}
\text { Jumlah Yang tidak Muncul } \\
\text { Berahi dalam 1 Siklus berahi }
\end{array}}{\text { Jumlah Ternak yang di IB }} \times 100 \%
$$

Kemudian data yang diperoleh dianalisis secara deskriptif analitik dan di uji chisquare. Hoesni (2015) menambahkan bahwa rumus uji chi-square adalah sebagai berikut :

$$
\mathrm{X}^{2}=\frac{(O-\theta)^{\theta}(O-\theta)}{0}
$$

Keterangan :

$\mathrm{O}=$ Pengamatan

$e=$ Harapan

Dalam memperkuat hasil penelitian, maka di analisis pula data pendukung mengenai kualitas berahi dan pakan. Pakan yang diberikan berupa konsentrat, hijauan dan jerami dengan frekuensi pemberian sebagai berikut : pagi diberikan hijauan, kemudian jerami, dan siang diberikan konsentrat. Heat detector merupakan alat yang digunakan untuk mengetahui kualitas berahi dengan skala angka 1- $60 \Omega$ pada penelitian HD digunakan untuk memastikan ternak dalam kondisi berahi ditandai dengan munculnya angka $30-40 \Omega$

\section{HASIL DAN PEMBAHASAN}

\section{Pengaruh waktu IB terhadap keberhasian IB pada Sapi Brahman Cross}

Hasil nilai Conception Rate (CR) pada penelitian ini didapatkan bahwa IB pada sapi Brahman Cross dengan menggunakan interval $0-4$ jam menunjukkan angka kebuntingan lebih tinggi dibandingkan dengan IB menggunakan interval 8-12 jam. Diagram keberhasilan IB pada sapi Brahman Cross berdasarkan $\mathrm{NRR}_{1} \quad(\mathrm{P}<0,05)$ disajikan pada Gambar 1.

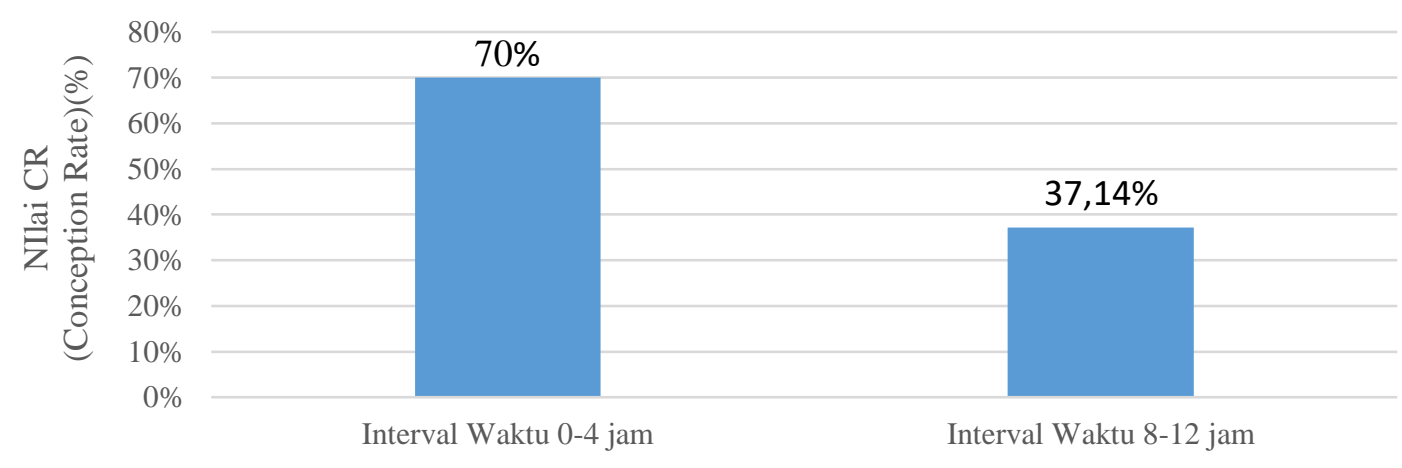

Interval Waktu IB

Gambar 1. Diagram hasil CR menggunakan $\mathrm{NRR}_{1}$ pada sapi Brahman Cross dengan perbedaan interval waktu inseminasi buatan

Gambar 1. IB yang dilakukan pada interval 0-4 jam setelah munculnya tandatanda berahi sesuai dengan waktu ovulasi pada sapi Brahman Cross yaitu 22 jam setelah berahi, sedangkan sapi Brahman
Cross yang di IB pada interval 8-12 jam setelah munculnya tanda-tanda berahi masa ovulasinya terlambat yakni pada jam ke 26-30. Dirjen Peternakan (2008)menyampaikan waktu 18 jam 
adalah waktu yang baik untuk melakukan IB pada sapi Brahman Cross dengan tanda-tanda berahi sebagai berikut : diam dinaiki, sering melenguh, gelisah, menaiki temannya, nafsu makan menurun, vulva merah, bengkak, hangat dan keluar lendir. Hal tersebut sesuai dengan penelitian yang dilakukan, yakni mengamati tanda-tanda berahi pada sapi Brahman Cross dengan kriteria 3A (Abang, Aboh, Anget).

Menurut Tambing dkk. (2000) untuk terjadi fertilisasi, spermatozoa membutuhkan waktu kapasitasi selama 56 jam pada saluran organ reproduksi betina. Fenton dan Martinez (1980) dalam jurnal Pemayun (2014) menjelaskan bahwa angka kebuntingan terjadi sebanyak $68,32 \%$ pada sapi Holstein yang di IB 12 jam setelah kemunculan tandatanda berahi, hal tersebut dikarenakan ditambah kapasitasi agar mencapai waktu ovulasi. Pada sapi Brahman Cross ovulasi terjadi pada jam ke 22 setelah berahi (Dirjen Peternakan, 2008). Keberhasilan kebuntingan pada penelitian ini berdasarkan hasil dari $\mathrm{NRR}_{1}$. Hal tersebut sejalan dengan Fernanda (2014) Pemeriksaan kebuntingan dengan NRR dilakukan dengan 3 metode, yakni $\mathrm{NRR}_{1}$ (0-21 hari), $\mathrm{NRR}_{2}$ (22-42 hari), dan $\mathrm{NRR}_{3}$ (43-63 hari). NRR ${ }_{0-21}$ diamati pada hari ke 18-21, NRR 22-42, diamati mulai hari ke 3942, dan NRR 43-63 diamati mulai hari ke 6063. Sapi yang menunjukkan tanda-tanda berahi setelah IB ke 3 maka di anggap gagal.

Penyebab terjadinya keterlambatan berahi pada sapi Brahman Cross adalah lingkungan dan genetik. Menurut Sumadi dan Siliwolu (2004) sapi Brahman Cross mengandung darah Hereford dan Shorthorn yang bukan merupakan sapi tropis. Selain itu munculnya sapi-sapi silangan seperti Brahman Cross terjadi perubahan genetik beserta fisiologisnya. Perubahan atau kombinasi gen ini yang kemudian memunculkan perubahan negatif ataupun positif, sehingga sapi hasil silangan memiliki produksi dan reproduksi yang kurang baik dibandingkan dengan sapi indukannya.

Syaifuddin (2011) menambahkan bahwa reproduksi sapi Brahman Crossmasih cenderung jelek, karena memiliki memiliki Service per Conception 2,27. Angka yang tinggi tersebut mengakibatkan sapi Brahman Cross harus di IB lebih dari 1 kali. hal tersebut didukung oleh Diwyanto dan Inounu (2009) yang menyatakan bahwa sapi silangan S/C cenderung semakin meningkat, yang rata-rata di atas dua, bahkan untuk beberapa kasus banyak kejadian nilai S/C dapat mencapai di atas tiga, sehingga beranak lebih dari 18 bulan.

\section{Hasil pengukuran Heat Detector}

Salah satu alat yang digunakan untuk mengetahui atau medeteksi berahi pada sapi menggunakan alat yang bernama heat deterctor (HD). Pembacaan HD diambil dengan cara memasukkan pendeteksi secara hati-hati dalam vagina, pengukuran akan berlangsung cepat dan direkomendasikan 2 kali pembacaan dalam sehari untuk mengetahui keadaan berahi. Rataan pengukuan kualitas berahi menggunakan HD disajikan pada Gambar 2. 


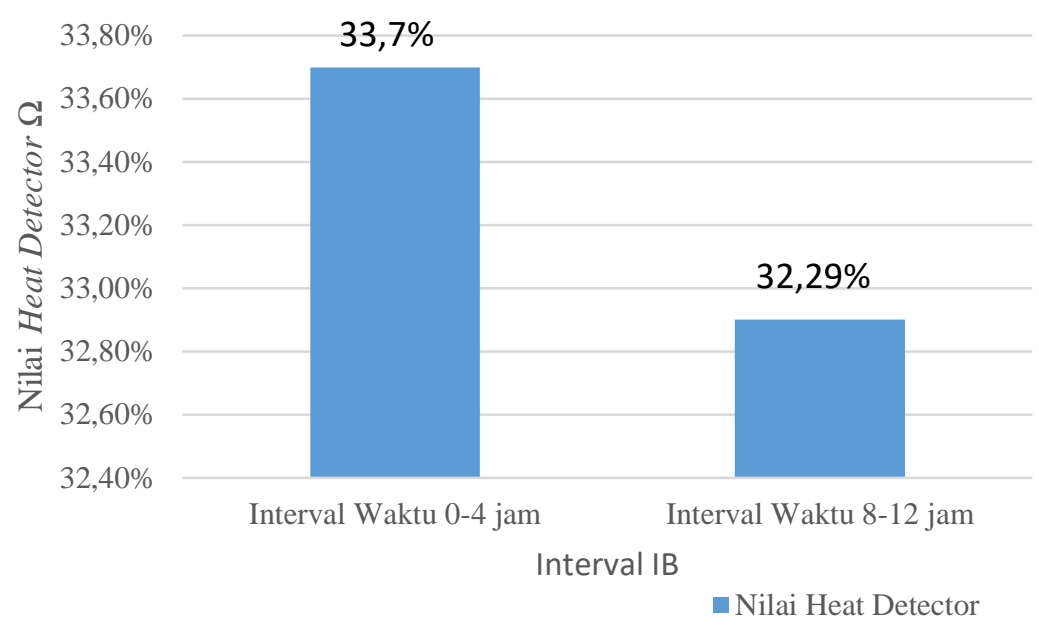

Gambar 2. Diagram nilai rata-rata Heat Detector dengan interval waktu yang berbeda

Berdasarkan Gambar 2 dapat diketahui bahwa rata-rata dari nilai $\mathrm{HD}$ yang digunakan pada perlakuan IB 0-4 jam memiliki rata-rata yang lebih tinggi dibandingkan dengan nilai HD pada perlakukan IB 8-12 jam, namun kedua perlakuan tersebut memiliki nilai range HD 30-40. Hal tersebut didukung oleh Pemayun (2014) yang menjelaskan HD adalah alat elektrik yang digunakan untuk menentukan ternak sedang berahi dengan memasukkan kedalam vagina secara pelan dan hati-hati hingga mencapai 20-30 cm, kemudian ditekan kedua tombol, dan jarum akan menunjukkan ke angka 30-40 jika ada tanda-tanda berahi, bila kurang atau lebih maka induk belum, sudah atau tidak sedang berahi.

\section{Hasil perhitungan pakan}

Perbandingan antara konsumsi nutrisi pakan dan kebutuhan pakan yang didapat dari Dirjen Peternakan (2008) disajikan pada Gambar 3 yang menyatakan bahwa pemberian pakan sesuai dengan kebutuhan pakan.

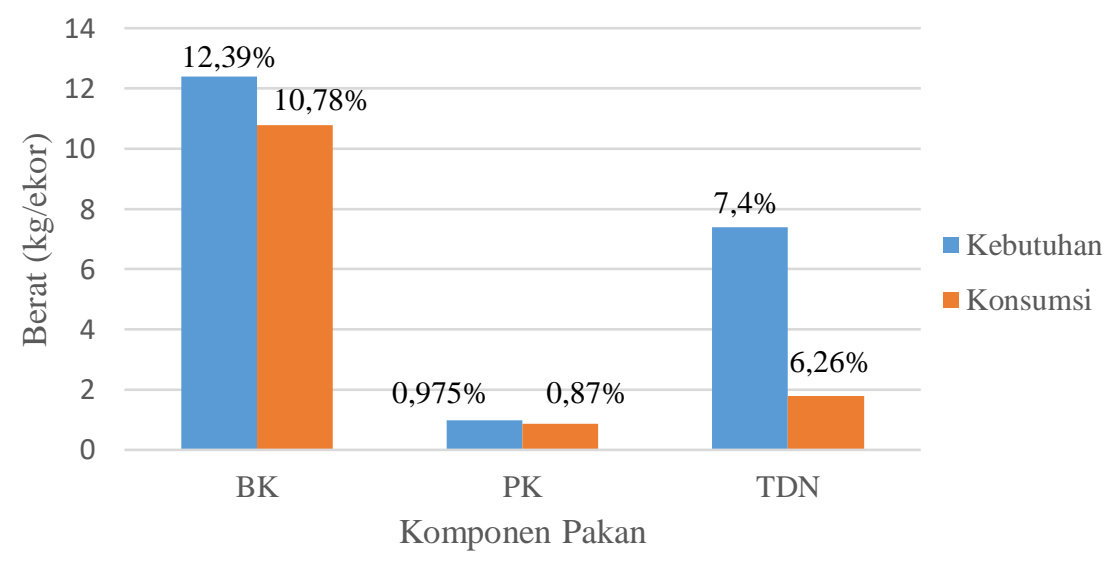

Gambar 3. Diagram perbandingan antara kebutuhan nutrisi dan konsumsi nutrisi pakan sapi Brahman Cross

Gambar 3 menunjukkan bahwa konsumsi nutrisi pakan ternak sapi Brahman Cross tidak tercukupi, didapatkan bahwa sapi Brahman Cross mengalami kekurangan nutrisi pakan dengan BK $-1,91$ kg/ekor, PK $-0,105$ 
kg/ekor, dan TDN $-1,14$ kg/ekor. Sehingga dapat mengakibatkan sapi Brahman Cross mengalami berahi yang kurang jelas ataupun keterlambatan berahi. Beberapa penelitian menunjukkan bahwa ternak yang diberi asupan pakan dengan kecukupan energi dan protein menyebabkan ternak lebih cepat tumbuh dan menunjukkan gejala berahi yang normal (Romano et al., 2005). Hal tersebut dibuktikan pada penelitian sapi di Nigeria Utara bahwa penambahan konsentrat kaya akan kandungan protein, karbohidrat dan campuran mineral akan memperlihatkan dewasa kelamin dan kebuntingan yang lebih cepat dibandingkan dengan sapi yang tidak mendapatkan tambahan nutrisi yang cukup (Yendraliza, 2013). Hal tersebut didukung oleh hasil penelitian yang menyatakan bahwa pemberian pakan belum sesuai dengan kebutuhan pakan.

\section{KESIMPULAN}

Berdasarkan hasil penelitian, dapat disimpulkan bahwa Inseminasi Buatan yang dilakukan pada sapi Brahman Cross dengan interval waktu 0-4 jam memiliki nilai persentase kebuntingan lebih baik, yakni $70 \%$ dibandingkan dengan IB yang dilakukan dengan interval 8-12 jam yang hanya 37,14\%.

\section{UCAPAN TERIMAKASIH}

Peneliti mengucapkan terimakasih kepada PT. Pasir Tengah yang memberikan fasilitas selama penelitian berlangsung.

\section{DAFTAR PUSTAKA}

Direktorat Jendral Peternakan. 2008. Petunjuk Pemeliharaan Sapi Brahman Cross. BPTU Sembawa Dirjen Peternakan.
Diwyanto, K., dan I. Inounu. 2009. Dampak Cross Breeding Dalam Program Inseminasi Buatan Terhadap Kinerja Reproduksi Dan Budidaya Sapi Potong. Wartazoa. 19 (2) : 93102.

Fernanda, M. Thoriq., T. Susilawati dan N. Isnaini. 2014. Keberhasilan IB Menggunakan Semen Beku Hasil Sexing Dengan Metode Sentrifugasi Gradien Densitas Percoll (SGDP) Pada Sapi Peranakan Ongole (PO). Jurnal Ilmu-Ilmu Peternakan. 24 (3) $: 1-8$.

Firdausi, A., T. Susilawati., M. Nasich dan Kuswati. 2012. Pertambahan Bobot Badan Harian Sapi Brahman Cross Pada Bobot Badan Dan Frame Size Yang Berbeda. Jurnal Ternak Tropika. 13 (1) : 48-62.

Hoesni F. 2015. Pengaruh Keberhasilan Inseminasi Buatan (IB) Antara Sapi Bali Dara Dengan Sapi Bali Yang Pernah Beranak di Kecamatan Pemayung Kabupaten Batang Hari. Jurnal Ilmiah Universitas Batanghari Jambi. 15 (4) :20-27.

Ihsan, M. N 2010. Ilmu Reproduksi Ternak. Malang : UB Press.

Jainudeen M. R and E.S.E. Hafez. 2008. Cattle and Buffalo. In Farm Animal Reproduction ed by B. Hafez / E.S.E. Hafez Balckwell Publish : 159-172.

Pamayun, T.G.O., I.N.B. Trilaksana dan M.K. Budiasa. 2014. Waktu Inseminasi Buatan yang Tepat pada Sapi Bali dan Kadar Progesteron pada Sapi Bunting. Jurnal Veteriner. 15 (3) : 425-430.

Ramli, M., T.N. Siregar, C.N. Thasmi, Dasrul, Sriwahyu dan A. Sayuti. 2016. Hubungan Antara Intensitas Estrus Dengan Konsentrasi 
Estradiol Pada Sapi Aceh Pada Saat Inseminasi. Jurnal Media Veterinaria. 10 (1).

Romano, M.A., W. H. Barnabe., A. E. D. F. Silva and Freites. 2005. The effectof nutritional level on advancing age at puberty in Nelore heifers. Ambiencia Guarapuava PR. 1:157-167.

Sugiarti, T. dan B. S. Siregar. 1999. Dampak Pelaksanaan Inseminasi Buatan (IB) Terhadap Peningkatan Pendapatan Peternak Sapi Perah Di Daerah Jawa Barat. Jurnal Ilmu Ternak dan Veteriner. 4 (1) : 1-6.

Sumadi dan Siliwolu. 2004. Penelitian Mutu Genetik Sapi Ongole dan Brahman di Kabupaten Sumba Timur, Nusa Tenggara Timur. Lokakarya Nasional Sapi Potong : 31-41.

Susilawati, T. 2011. Spermatology. Malang : UB Press.
Susilawati, T. 2011. Tingkat Keberhasilan Inseminasi Buatan Dengan Kualitas dan Deposisi Semen yang Berbeda Pada Sapi Peranakan Ongole. Jurnal Ternak Tropika. 12 (02) : 15-24.

Syaifuddin, N. A., dan W. Anis. 2011. Peningkatan Reproduksi Sapi Induk Brahman CrossPost Partum Dengan Pemberian Pakan Suplemen Multinutrient Block Plus Medicated. Jurnal Ilmiah Aplikasi Isotop dan Radiasi. 127-143.

Tambing, S.N., M. R. Toelihere dan T. L. Yusuf. 2000. Optimasi Program Inseminasi Buatan Pada Kerbau. Wartazoa. 10 (2) : 41-50.

Yendraliza. 2013. Pengaruh Nutrisi dalam Pengelolaan Reproduksi Ternak. Kutubkhana. 16 (01) :20-26.

Zajulie, M. I., M. Nasich., T. Susilawati dan Kuswati. 2015. Distrsi Komponen Karkas Sapi BrahmanCross (BX) Hasil Penggemukan Pada Umur Pemotongan yang Berbeda. Jurnal Ilmu-Ilmu Peternakan. 25 (1) : 2434. 